\title{
Revisiting the Origin of Printing: Birthplace, Time, and Social Factors
}

\author{
XIN Deyong 辛德勇1
}

(Department of History, Peking University, Beijing 100871, China)

\begin{abstract}
A re-examination of the artifacts and research pertaining to woodblock printing reveals that The Great Dharani Sutra of Immaculate and Pure Light (Mugujeonggwang Daedaranigyeong 无垢净光大陀罗尼经) in the Seokgatap Pagoda at the Bulguksa Temple, Gyeongju, South Korea unlikely originated in Korea and therefore cannot corroborate the claim that Korea is the birthplace of woodblock printing. It can be inferred from the earliest woodblock-printed Dharani sutra, dating from the Tang dynasty, that printing was invented no earlier than Emperor Xuanzong's Kaiyuan era (713-741). The most significant social factor for the invention of woodblock printing is the transmission of Yoga Esotericism from India to China, where it prevailed and prompted the evolution of duplicating sutras from separate-plate stamping to woodblock printing using a whole block and from the Sanskrit prints to the Chinese ones. Keywords: the origin of woodblock printing, The Great Dharani Sutra of Immaculate and Pure Light, Yoga Esotericism, stamping

摘 要：通过对相关文物及论述的重新检视，提出韩国庆州佛国寺所出《无垢净光大陀 罗尼经》是不可能刻印于朝鲜的, 也不能作为朝鲜发明雕版印刷术的依据。根据唐代最 早雕版印刷的陀罗尼经咒, 可以推测出印刷术产生的时间上限为唐玄宗开元年间。印度 瑜伽密教的入华及其在社会大众间的广泛传播, 正是促使印刷术产生最重要的社会因 素，并促成了在复制经咒时从分块捺印向整版雕印、从印制梵文向汉文的演变。 关键词：雕版印刷术起源, 《无垢净光大陀罗尼经》, 瑜伽密教, 捺印
\end{abstract}

$\mathrm{T}$ he herein mentioned "printing," refers to woodblock printing, or more accurately, the woodblock printing technique for producing books. It is widely acknowledged that this technique originated from East Asia, though the precise location, period, and social factors behind the invention of printing have yet to be fully and reasonably explicated in the global academic community. In recent years, the author has made

Received: March 31, 2020. Revised: March 17, 2021.

This article was translated into English by Lü Xin 吕昕, and copyedited by Elizabeth Hughes.

1 Research interests: Chinese historical geography, historical bibliography, and the history of geography. 
systematic analyses on these topics, yielding certain novel views. The following sections will provide evidence to support author's conclusions of the birthplace of printing, the time of its invention, and the social factors surrounding its development.

\section{The birthplace of printing}

China had been globally recognized as the birthplace of printing until a discovery in 1966 threw it into question. An ancient printed scroll of Buddhist sutra was found inside the Seokgatap Pagoda at the Bulguksa Temple, Gyeongju, South Korea (Figure 1). The Bulguksa Temple was built in the Silla kingdom, and this scroll was enshrined in a "gilt-bronze sarira reliquary" and placed in a small niche (referred to as the sarira hole in South Korea) on the second floor of the pagoda (Yi 1968, 458-461).

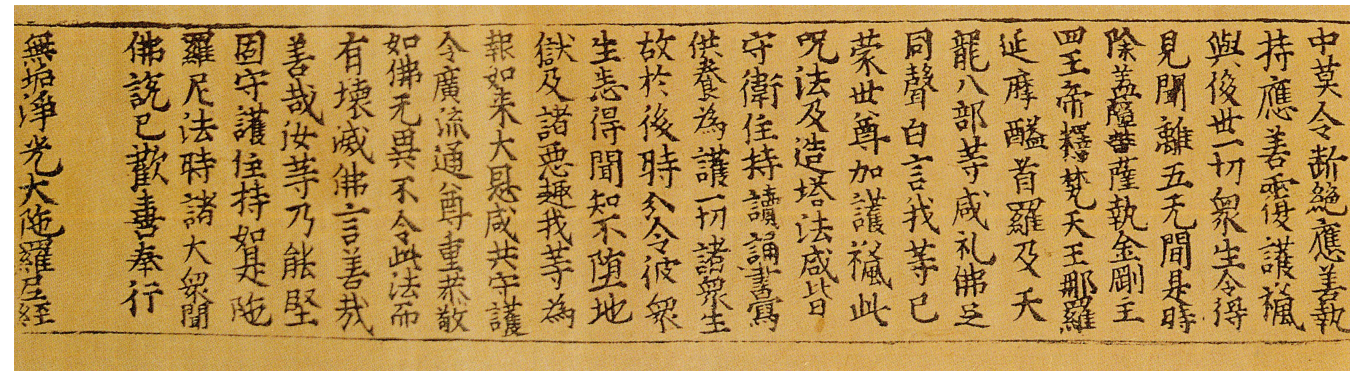

Figure 1: The Great Dharani Sutra of Immaculate and Pure Light (Mugujeonggwang Daedaranigyeong 无垢净光大陀罗尼经) in the Seokgatap Pagoda at the Bulguksa Temple, Gyeongju, South Korea (partial).

Although the printing date was unmarked on the scroll, the characters carved on the woodblock could help trace this print far back in history. South Korean scholars identified 751 as the year of construction of the pagoda. Further information indicated that the niche storing the sutra was sealed after the establishment of the Seokgatap Pagoda and had remained closed ever since-meaning the scroll was printed no later than 751, the tenth year of the Tang Emperor Xuanzong's Tianbao era, namely the tenth year of the Silla King Gyeongdeok's reign (Goodrich 1967, 377). Later analysis of the special characters printed on the scroll, which were coined during Wu Zetian's reign (690-705), led other South Korean scholars to infer that the scroll was woodblock-printed in the Silla period during Wu Zetian's reign (Kim 1994; Kim 2003).

If this assumption stands, and due to the absence of historical documents or cultural relics to prove the existence of printing prior to this scroll, this particular scroll in the Seokgatap Pagoda could be the world's earliest print; South Korea, where the sutra was printed, would be regarded as the new origin of printing. As a result of these findings, some South Korean scholars expressed their strong support of the theory that printing 
originated on the Korean Peninsula. This new evidence radically clashed with long-held knowledge of print history, and most scholars around the world were circumspect and implicit about their stances, while some from the Chinese Mainland opposed it vehemently (Zhang 1988; Li 1990, 179-190; Needham and Tsien 1985, 150-151; Qigong 1997). Both sides presented copious amounts of plausible evidence. In the author's view, however, both the South Korean and the Chinese sides are lacking sufficient proof to either corroborate or refute the opposing claims.

The author's consideration on this subject starts with the evident contradiction between the essence of the Buddhist scroll and how it was stored in the pagoda. The scroll found in the Seokgatap Pagoda contains multiple kinds of mantras in Buddhist Vajrayana and is titled The Great Dharani Sutra of Immaculate and Pure Light (hereafter The Great Dharani Sutra), whose Chinese translation gained in popularity and was widely venerated in such places as Tang China, Silla, and Japan. One significant reason for this popularity lies in people's belief in the sutra's wondrous power to dispel defilement, extinguish sin, and prolong longevity. The sutra states, however, that in order to properly fulfill such functions, a large number of replicas must be enshrined and worshipped. This requirement could shed significant light on the scroll's printing location debate. The Root Dharani Mantra (Genben Tuoluoni zhou 根本陀罗尼咒)， for instance, requires worshipers to

write seventy-seven copies of the mantra. ... Alternatively seventy-seven miniature clay pagodas should be made, each of which holds one copy to worship. These steps duly undertaken, those who are about to die will prolong their lives, and all the previous sins and evil deeds will be removed. They will permanently escape from the hell and from the realms of hungry ghosts and animals. In the next life, they will always know the things that happened in the former life and have all the wishes fulfilled. . . All diseases and troubles will be eliminated.2

Another example can be found in the Dharani inside the Chattra (Xiangluntang zhong Tuoluoni zhou 相轮橖中陀罗尼咒), which requires that

a pious worshipper should duly write ninety-nine copies of the mantra, which are placed around the chattra (parasol), and write copies of this mantra and functions, which are concealed inside the chattra. In doing so, it is equivalent to the construction of 99,000 chattras, the enshrining of 99,000 Buddha sariras, the erection of 99,000 sarira pagodas, and the building of 99,000 Eight Great Stupas and of 99,000 Bodhimanda pagodas. . . . Those who want to fulfill the Six Perfections (Paramita) should . . . write ninety-nine copies for each of the first four Dharani mantras, each of which should be placed in ninety-nine hand-made miniature pagodas. ... Those who resolutely follow this dharma

2 “书写此咒满七十七本……或作小泥塔满足七十七, 各以一本置于塔中而兴供养。如法作已, 命 欲尽者而更延寿, 一切宿障、诸恶趣业悉皆灭尽, 永离地狱饿鬼畜生。所生之处, 常忆宿命, 一切 所愿皆得满足……切众病及诸烦恼咸得消除。” 
will attain the Six Perfections, ... which is equivalent to making offerings to nine billion, nine hundred million, one hundred thousand nayuta (an inconceivably large number) of Tathagatas, Arhats, and Perfectly Enlightened Buddhas. ${ }^{3}$

Other mantras of The Great Dharani Sutra provide abundant examples of making copies in order to gain blessings (Mitrasanta et al. 1927, 718-721). On account of this command, the “One Million Pagoda Dharani” (Hyakumanto Darani 百万塔陀罗尼) in Japan originated from Empress Shotoku's order in 764 that one million copies of The Great Dharani Sutra should be printed and put inside one million pagodas, although this amount was perhaps unattainable in reality. Another example can be found in the woodblock-printed Root Dharani Mantra, which was uncovered during the late 1980s and early 1990s in a sarira pagoda in old Qingzhou dating from the Liao dynasty (9071125) and was part of Dharani on the Rod (Zhanggan Tuoluoni 枨竿陀罗尼). Other parts included the Sanskrit Dharani inside the Chattra, engraved on red copper plates (or bronze ones with gold foils), and the woodblock-printed Records of Placing the DharmaSarira inside Buddha-Shaped Statues (Foxingxiang zhong anzhi fasheli ji 佛形像中安置法 舍利记). Each of the 106 copies in total of Root Dharani Mantra were concealed in a miniature dharma-sarira pagoda. These practices were conducted in accordance with the stipulated patterns in reverence of The Great Dharani Sutra. The dharma-sarira pagodas in Qingzhou of the Liao dynasty, in particular, were arranged around the chattra. A stone stele (dating from 1049, the eighteenth year of the Liao Emperor Xingzong's Chongxi era) was found inside a sarira pagoda, and the inscription reads:

On the fifteenth day of the seventh lunar month that year, the golden dharma sarira (jin fa sheli 金法舍利) was placed inside the cavity of the chattra, with ninety-nine copies of Dharani on the Rod and other instruments on four sides-all practices of enshrinement strictly adhered to the dharma. (De, Zhang, and Han 1994)4

These practices match the aforementioned directions in The Great Dharani Sutra. Furthermore, a silver plaque with the inscription "a pious worshipper should duly write ninety-nine copies of the mantra, which are placed around the chattra," more explicitly stresses the sutra's requirement of enshrining mantras in large quantities. Given the above pattern, it would seem unreasonable that only one scroll of The Great Dharani Sutra would be stored in the Seokgatap Pagoda at the Bulguksa Temple for

3 “善男子应当如法书写此咒九十九本, 于相轮橖四周安置, 又写此咒及功能法, 于橖中心密覆安 处。如是作已, 则为建立九万九千相轮橖已, 亦为安置九万九千佛舍利已。亦为已造九万九千佛舍 利塔, 亦为己造九万九千八大宝塔, 亦为己造九万九千菩提场塔。……若复有人欲得满足六波罗蜜 者, 当……写前四种陀罗尼咒各九十九本, 手作小塔满九十九, 于此塔中各置一本。……若依此法 而受持者, 六波罗蜜悉皆成满, ……是则供养九十九亿百千那由他如来应正等觉。”

4 “当年七月十五日, 于相肚中安置金法舍利, 并四面安九十九本枨竿陁罗尼, 及诸供具, 莫不依 法鉌至严洁安置供养。” 
worshiping if it had been prolifically printed in Silla. What is particularly noteworthy is that the Japanese scholar Kawase Kazuma 川濑一马 (1906-1999) concluded upon his examination of this scroll of The Great Dharani Sutra that this edition was not the first print. He stated that the scroll showed signs that the printing block had been utilized for some time, and therefore the scroll was a later print. Kawase believed that the sutra enshrined in a pagoda should have been hand-written to indicate the prayers' piety. Furthermore, if a printed copy had replaced the handwritten scroll, the first print of a newly carved block would have been used. Since the sutra in the Seokgatap Pagoda is a later print and the only copy, it implies that the worshipper highly regarded this particular print, meaning Silla may have specifically requested it from Tang China (Kawase 1984).

In the meantime, the inscription on an artifact unearthed in South Korea indicates that in the second lunar month of the third year (883) of the Tang Emperor Xizong's Zhonghe era, namely the ninth year of Silla King Heongang's reign, Bhadanta Xuanyu 玄余 from the Bomunsa Temple in Silla was recorded to have

built seventy-seven miniature pagodas following The Great Dharani Sutra and wrote seventy-seven copies to place in the big pagodas. He extended his wish that every household could hold wondrous treasures, that everyone could gain miraculous pearls. ... Hence, great deeds could be achieved and people could gain enlightenment together. (Yi 1968, 480-481)5

This account reveals two critical points. First, the Silla kingdom on the Korean Peninsula, strived to meet the requirement of producing sufficient numbers of scrolls when making such mantras, similar to China. Second, these seventy-seven copies of mantras were still hand-written, implying that woodblock printing had not yet been adopted in Silla at that time. The Korean media later disclosed that documents in the Northern Song Emperor Renzong's reign were found in the same niche storing the scroll of The Great Dharani Sutra, thereby disqualifying 751 as the latest year when this scroll was printed (The Chosun Ilbo 2007). Thus, the possibility that this scroll of The Great Dharani Sutra was printed in South Korea must be excluded.

In the question of whether the Chinese Mainland or the Korean Peninsula had the requisite conditions for the application of woodblock printing, the overall cultural conditions and Buddhist culture of Silla lagged far behind those of the Tang dynasty; notably, Tang craftsmen supervised the construction of the Bulguksa Temple. Taking this historical background into account, a definite inference can be made that the scroll of The Great Dharani Sutra was by no means printed in Silla, meaning the invention of

5 “依《无垢净光经》造小塔七十七躯, 写真言七十七本, 安处大塔。愿言表示家家有妙宝, 人人 得灵珠。……因此胜业, 共证菩提。” 
printing could not have begun on the Korean Peninsula. Additionally, the fact that this solitary sutra was solemnly enshrined by the Silla kingdom indicates that it was a rare and treasured object. If Silla already had a local woodblock print culture, this scroll would not have been so greatly valued. Thus, China remains the only possible origin of woodblock printing.

\section{The time when printing was invented}

By the Ming and Qing dynasties in China, various dates of the invention of printing had already been proposed. To date, theories range from the Western Han dynasty to the Tang dynasty, but there is declining support for a date of origin prior to the Sui dynasty. This section will therefore begin with a few representative arguments and then propound the author's opinion.

The Sui dynasty (581-618) was put forward as the period of the invention of printing no later than the Jiajing era (1522-1566) in the Ming dynasty. The supporters presented multiple historical documents and even objects related to printing. However, minute analysis exposes misinterpretations and misjudgments of these documents. Therefore, this section will not dwell on these historical opinions. Yet recent claims from the end of the twentieth century cite a new piece of supposed evidence that merits our attention (Figure 2).

The figure is captioned as the Woodblock Colored Buddha Image of the Sui Dynasty in Dunhuang (敦煌隋木刻加

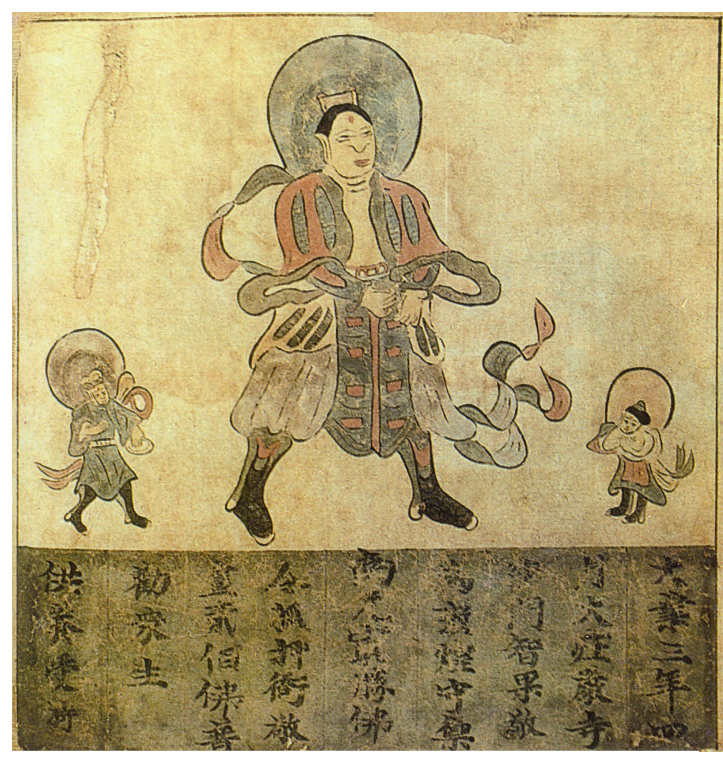

Figure 2: The so-called Buddha image in the third year of the Daye era in the Sui dynasty (sold by Christie's Auction House). 彩佛像) with the inscription "the third year (607) of the Daye era" (Daye sannian 大业三年). It was sold in late 1983 by Christie's Auction House in New York, US. This print was later purchased by an authority in China and served as the earliest physical evidence of woodblock printing. Some researchers held that it could sufficiently vindicate the Sui dynasty as the origin of printing and "draw a clear conclusion for the thousand-year-long contention" (Xiao 2000; 
Zhang 2000; Chen 2000). ${ }^{6}$

Although this statement appeared justifiable, the Buddha figure was later proven to be a counterfeit made by Chinese antique merchants in the 1920s, hand-drawn rather than woodblock printed. Antique merchants forged a batch of similar Buddha images, some of which were purchased by Japanese collectors who published two in the Kokka 国华 journal (Figure 3) (Hundunsheng 1925).
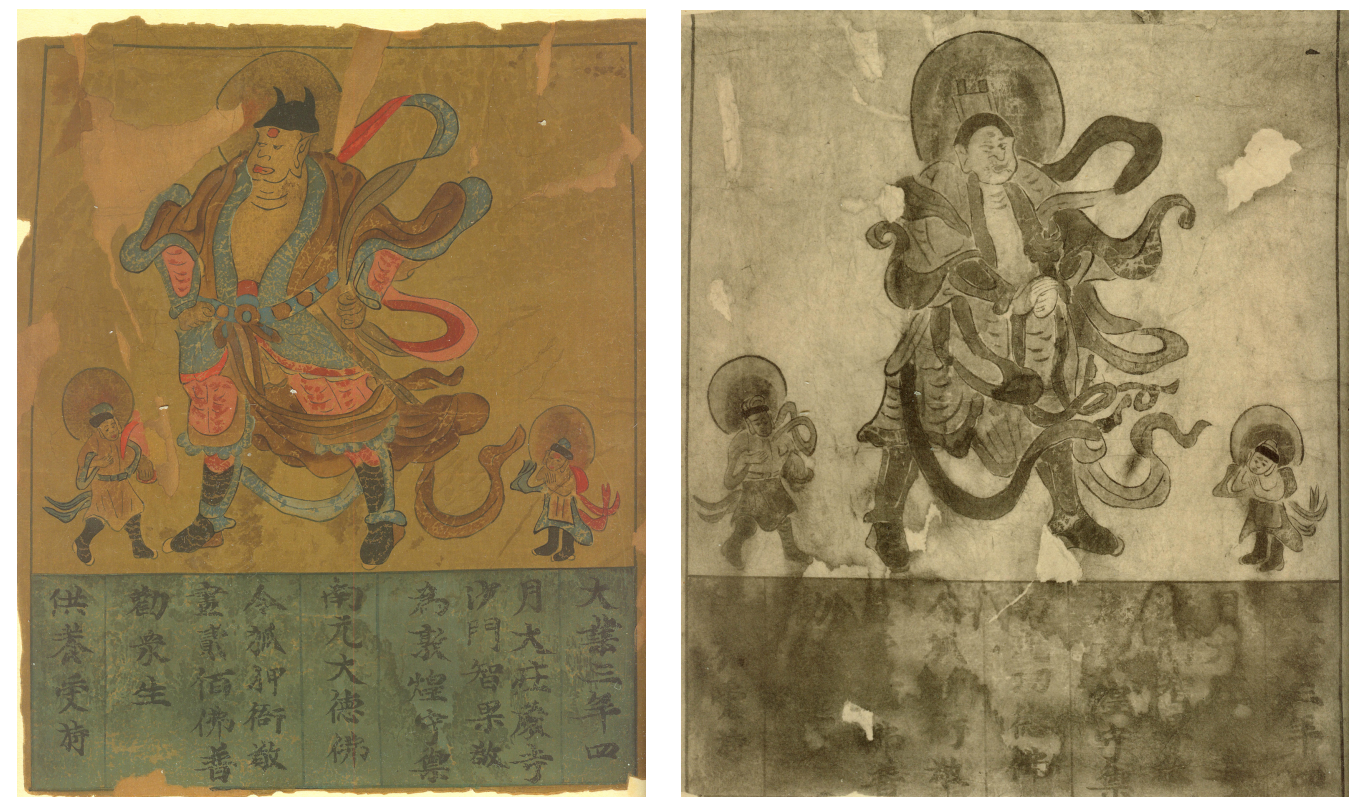

Figure 3: The two so-called Buddha images in the third year of the Daye era in the Sui dynasty published in Kokka (Hundunsheng 1925).

This publication widely appealed to the Japanese academic community in history, archaeology, and art history. Kuwabara Jitsuzo 桑原篤藏 in the history of Japan, Nakayama Kyushiro 中山久四郎 in the history of printing, and the collector Nakamura Fusetsu 中村不折 in art history, all meticulously examined these Buddha figures, which they thought to be unquestionably fake (Kuwabara 1968, 99; Nakamura 2003, 2-3; Nakayama 1930, 492-495). Since then, Japanese scholars in the history of printing in China have not regarded these Buddha images as ancient prints. In the 1970s, Kanda Kiichiro 神田喜一郎 re-emphasized the Japanese academic community's consensus on this issue and underlined that they had not found one single convincing object or document that proved printing occurred during the Sui dynasty (Kanda 1976). The Buddha image auctioned by Christie's bears striking similarities to the counterfeits from the 1920s, explicitly revealing itself to also be a hand-drawn fake. The seemingly

6 “为持续了上千年的争论, 做了一个明确的结论。” 
solid evidence is thus rendered groundless.

Another view holds that printing dates back to the Tang Emperor Taizong's reign (627-649), which Zhang Xiumin 张秀民 in the history of printing in China staunchly supported (Zhang 1958, 59-60). Hu Shi 胡适 and others, however, already noted that the historical materials referred to by Zhang were too late to be reliable (Hu [1959] 1998, 278). Those professionally trained in history or understanding basic methods for historical research mostly dismissed this idea.

However, a Dharani sutra print in Sanskrit (Figure 4), collected by the Xi'an Antique Administration Committee (XAAC) in 1974, was seen by some as a new proof for the aforesaid standpoint, which was seemingly verified in late 1996 when the Shaanxi Provincial Cultural Relics Appraisal Committee organized experts to undertake a collective appraisal (Pan 1997; Pan 2002, 118). This specific appraisal, however, did not produce any cogent evidence.

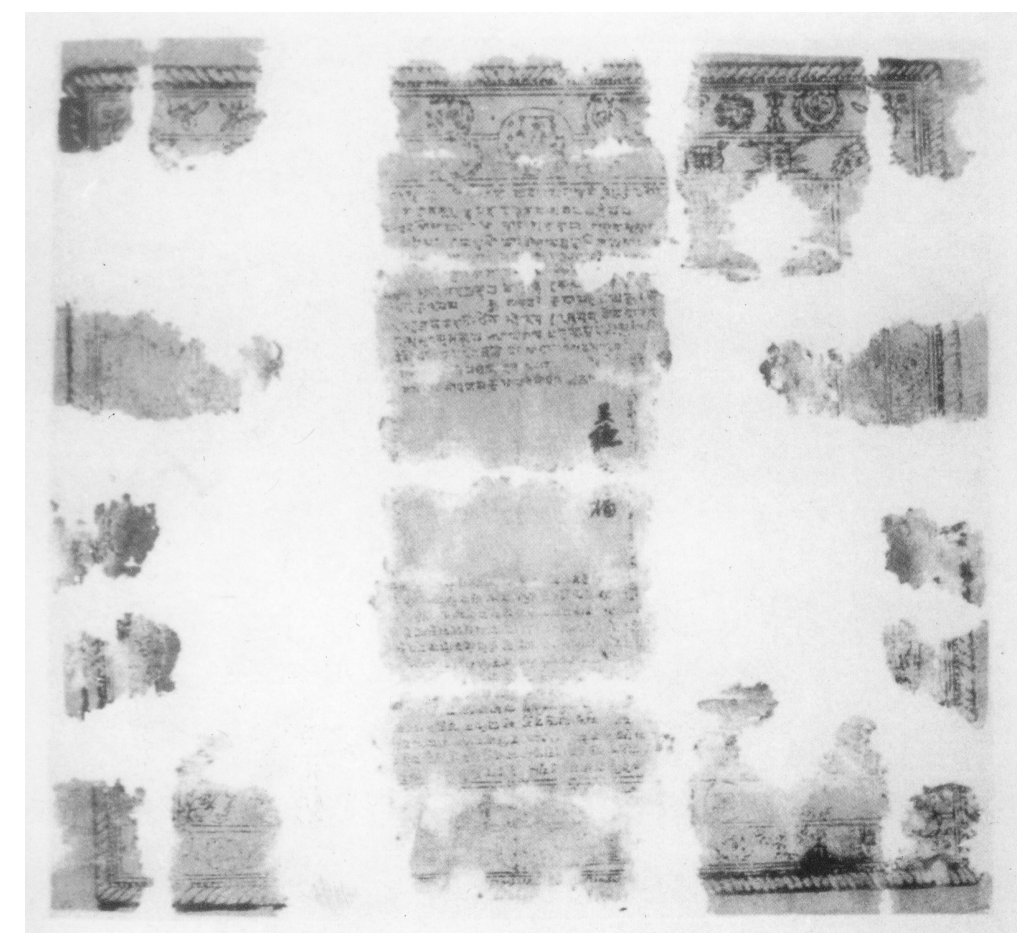

Figure 4: Mahapratisara Dharani Sutra 大随求陀罗尼经 collected by the XAAC (unearthed from the Xi'an Xijiao Diesel Engine Works) (Su 1999, 125).

Nevertheless, other evidence exists that shows that Sanskrit Dharani sutras are indeed the earliest woodblock prints, which will be elaborated on in the third section. To identify the printing time of this Dharani sutra requires analyses on related academic backgrounds. First and foremost, the name or the type of the printed sutra 
should be made clear. Although this Dharani sutra was printed in Sanskrit, the popularity of the Sanskrit prints in China came about following the wide dissemination of Chinese translations of the original Sanskrit. New Sanskrit versions were only made after the Chinese translations due to the common belief among the faithful that the Sanskrit copies were more effective. Secondly, all the Dharani sutras (be they Chinese, or Sanskrit, woodblock printed or hand drawn) that were excavated in Tang tombs with known conditions of their original storage are Mahapratisara Dharani Sutra (Suiqiu jide dazizai Tuoluoni shenzhou jing 随求即得大自在陀罗尼神咒经, namely Dasuiqiu Tuoluoni jing 大随求陀罗尼经) without exception. The Dharani sutra collected by the XAAC is, therefore, presumably the same Mahapratisara Dharani Sutra. Meanwhile, the earliest translation of Mahapratisara Dharani Sutra was made by the monk Manicinta 宝思惟 in Kaśmīra, North India. This translation, according to Li Ling 李领, could only have been accomplished between the second year (693) of Emperor Wuzhou's Changshou era and the second year (706) of Emperor Zhongzong's Shenlong era, and became popular after the first year (712) of Emperor Ruizong's Taiji era (Li 2011, 185-187). For this reason, the Dharani sutra in Sanskrit collected by the XAAC is by no means a print made during the Tang Emperor Taizong's reign. Thirdly, the Dharani sutra belongs to Vajrayana. Considering the development of Vajrayana in the Tang dynasty and other Tang Dharani sutra prints with known printing time, a Mahapratisara Dharani Sutra of this sort could not have been printed earlier than the first year (713) of the Tang Emperor Xuanzong's Kaiyuan era. Hence, the physical object of this Dharani sutra cannot attest to the invention of woodblock printing during Emperor Taizong's reign.

Much of the scholarship that advocates a later invention date of printing specifically names Wu Zetian's reign (690-705). Of the substantial plausible evidence that supports a later date, one significant proof is the print of The Great Dharani Sutra found in South Korea, discussed in the first section on the birthplace of printing. Apart from this to-be-examined scroll, there was no record or physical remain to prove the application of printing in the Wu Zhou dynasty, meaning that the scroll of The Great Dharani Sutra is merely an isolated piece of evidence. The Wu Zetian-coined characters printed in The Great Dharani Sutra were thought to be proof of the scroll's printing origin in the territory of the $\mathrm{Wu}$ Zhou dynasty, which reinforced the belief of $\mathrm{Wu}$ Zetian's reign being the origin of printing. Wu Zetian's newly-coined characters, however, were actually abolished at the beginning of the first year (705) of the Tang Emperor Zhongzong's Shenlong era, though some remained in use over a period of time. Prior to that, within the sovereignty of Tang China, it is improbable that these coined characters would have been partly used or disregarded at one's free will. The $\mathrm{Wu}$ Zhou manuscripts found in places such as Dunhuang and Turpan indicate that even remote areas of western China submissively obeyed the court regulations. However, in the case of the print of The Great Dharani Sutra in South Korea, only part 
of the coined characters was adopted, meaning that the scroll could only be printed after the first lunar month of the first year of Emperor Zhongzong's Shenlong era instead of the $\mathrm{Wu}$ Zhou dynasty.

Toward the end of the scroll and definitively separated from the sutra text are six characters xin wei chu ri su lin 辛末除日素林, of which chu ri can only refer to the Chinese Lunar New Year's Eve of the Xinwei year. Other factors taken into account, if xin wei chu ri indicates when the woodblock was carved, then the earliest date could only be the nineteenth year (731) of Emperor Xuanzong's Kaiyuan era, meaning the earliest engraving year of the The Great Dharani Sutra must be 731. It thus further invalidates the theory that printing originated during the $\mathrm{Wu}$ Zhou dynasty.

Since the above statements are far-fetched, when was printing invented? A reasonable explanation may be found in credible documents or in historical relics with verifiable dates.

The earliest known indubitable written reference to woodblock printing is Prime Tortoise of the Record Bureau (Cefu yuangui 册府元龟) in which Feng Su 冯宿, a commander of Dongchuan, was documented to have proposed a decree "banning [unauthorized] almanac woodblocks" (jinduan yin liri ban 禁断印历日版) in the ninth year (835) of the Tang Emperor Wenzong's Taihe era (Wang et al. 1960, 1932). The Dunhuang document numbered Дх02880, held in Russia, is actually a fragment of the woodblock-printed "Almanac from the Eighth Year, jiayin, of the Tang Taihe era" (Tang Taihe banian jiayin sui juzhu liri 唐太和八年甲寅岁具注历日), a physical proof of print that indisputably justifies the credibility of Prime Tortoise of the Record Bureau.

The question is, then, how much earlier did printing exist? Scholars such as Thomas Francis Carter, Huang Yongnian 黄永年, and Su Bai 宿白 all assumed that printing was invented in the Tang Emperor Xuanzong's Kaiyuan era (Carter 1925, 29; Su 1999, 3; Huang 2005, 54). Although they all refer to significantly earlier historical documents than in Prime Tortoise of the Record Bureau, the records are in fact unreliable. If the time of printing invention is inferred from historical records alone, the date can be no earlier than the Kaiyuan era.

Another attempt could be made from the perspective of historical relics. Apart from the stamped figures of Buddha, the earliest prints from the Tang dynasty are Dharani sutras of Vajrayana, more specifically, Vajrayana mantras. At the end of the last century, Su Bai collected and analyzed the early prints of the Dharani sutra in Tang tombs and summarized the following patterns: the Sanskrit print precedes the Chinese one, and the print successively stamped using four plates precedes that using a whole woodblock (Su 1999, 3-4, 7-9, 124-127). The figures' style and clothing in the earliest known Dharani sutra at the time of Su's publication dates it "close to Emperor Xuanzong's reign (712-756)," and "indicates the last year (741) of the Kaiyuan era" in the analysis of certain features (An and Feng 1998). 
It should be noted that this print was produced by stamping, a technique that preceded woodblock printing. As a result, the earliest woodblock-printed Dharani sutra in the Tang dynasty, namely the earliest application of woodblock printing, could not have occurred earlier than the Kaiyuan era, in other words the earliest period of printing invention.

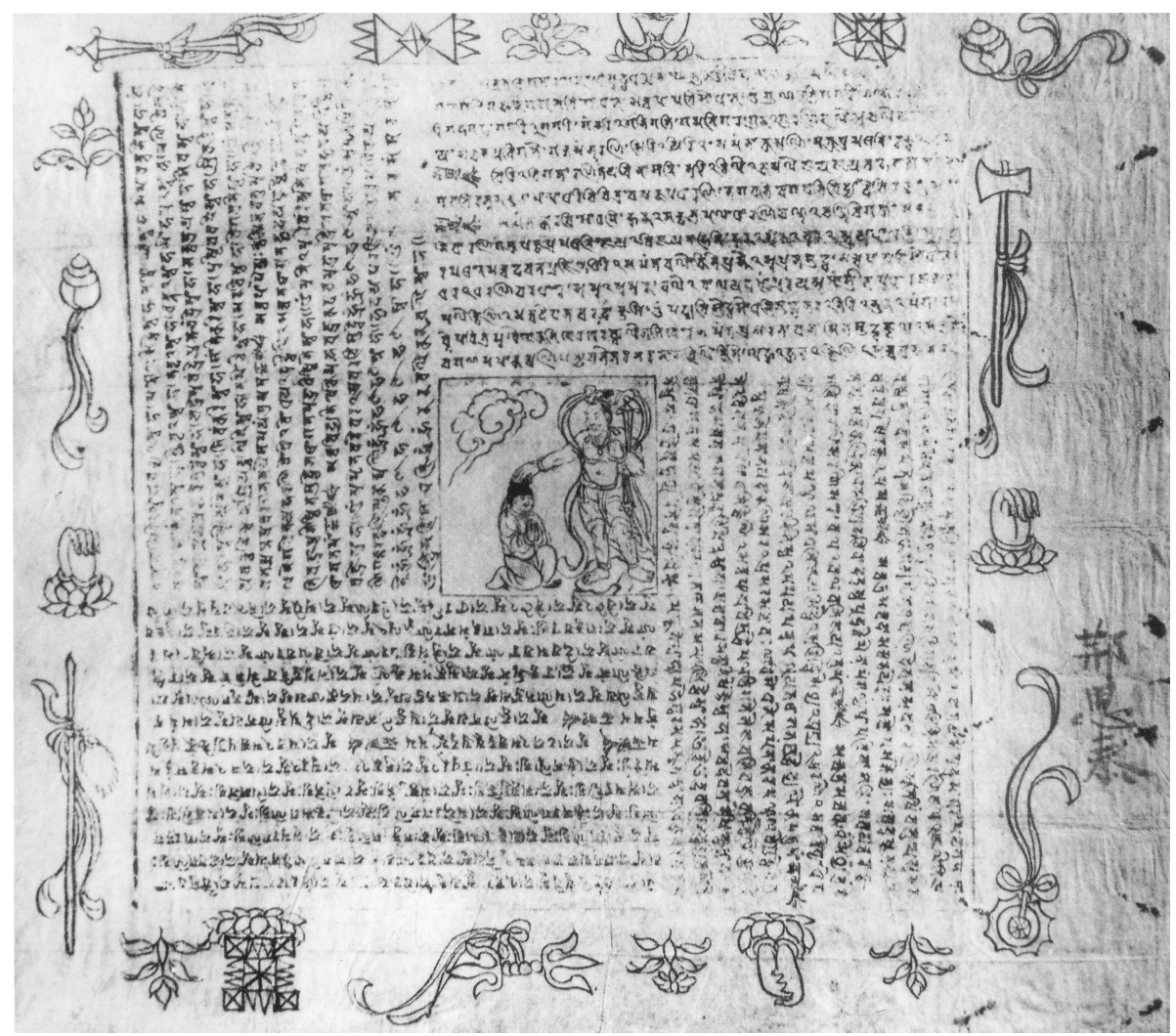

Figure 5: The earliest stamped Mahapratisara Dharani Sutra (unearthed from Xi'an Papermaking Mesh Factory) (Su 1999, 124).

\section{Social factors prompting the invention of printing}

Historical documents and relics point to the period after the Tang Emperor Xuanzong's Kaiyuan era (713-741) as the only possible origin of woodblock printing, which was not an accidental occurrence and was prompted by the underlying driving force-a key issue that must be thoroughly investigated in the discussion of printing's origin.

Many Chinese scholars seeking to establish the date of the origin of printing used to regard some seemingly pertinent factors as the technical origin or as the predecessor of printing. The most commonly cited examples are stamping and making rubbings from inscriptions, as well as evidence of print materials from the periods in question, such as 
paper and ink. It was widely maintained that the combination of stamping and making rubbings from inscriptions sufficed as evidence of the invention of printing.

However, the techniques of stamping and making rubbings from inscriptions were applied in China much earlier than woodblock printing was. Some researchers believed that seals were used in China no later than the middle of the Western Zhou dynasty (1046-771 BCE), some even tracing the history of seal utilization to the "three seals of the Shang dynasty (1600-1046 BCE)” (商代三玺), and that the rubbing technique was fully developed no later than the Southern dynasties (420-589). The proposal that woodblock printing was first invented after the High Tang era offers very few logical explanations consistent with historical facts.

As early as the 1920s, the question of the social circumstances surrounding printing was scrutinized in exceptional research by Fujita Toyohachi 藤田丰八 and Xiang Da 向达 (Fujita 1930, 6-12; Xiang 2001, 117-122). In the 1950s, Tokushi Yusho 秃氏祐祥 made more detailed elucidations (Tokushi 1951, 16-28; Tokushi 1981, 171-173). Unfortunately, the standpoints of Fujita and others were disregarded, leaving the social factors involved with printing effectively unknown until the present day, contributing to an incorrect date of origin for printing.

Fujita was the first to unravel the historical truth on this subject. His excellence among the counterparts was exemplified in the following three acute and unequivocal points: (1) woodblock printing directly stemmed from the stamping technique for Buddha images; (2) the stamping technique was transmitted from India to China; (3) people's religious beliefs solely contributed to the spread and evolution of such techniques. To put it another way, the stamping technique for Buddha figures dominated the precursory stages of printing. If China had not embraced this stamping technique from India, printing would have not been invented. Furthermore, if there had not been the demand driven by Buddhist beliefs among the Chinese, then woodblock printing would not have been attempted.

Discussions made by Fujita, Xiang, Tokushi, and others indicate that the Indian stamping technique using Buddha seals to stamp Buddha figures was brought to Tang China by Wang Xuance 王玄策 in the fifth year (660) of Emperor Gaozong's Xianqing era, or perhaps a year or two later. At that time, the abbot of the Mahabodhi Monastery, Silanaga 戒龙, specially presented four Buddha seals as valuable gifts to Wang, the Tang envoy. Yet, according to A Desultory Record of the Cloud Immortal (Yunxian sanlu 云 仙散录) and A Biography of the Tripitaka-Master of the Great Ci'en Monastery (Datang Da Ci'en Si Sanzang fashi zhuan 大唐大慈恩寺三藏法师传), Xuanzang introduced Buddha seals to Tang China upon his return from India in the nineteenth year (645) of the Zhenguan era (Feng 2006, 62, "print Puxian [Samantabhadra]" [印普贤]); Shi and Shi 1932, 1b-2a, 6a-7a). It means that before Wang brought back his gifts, such seals had already been applied to producing a large quantity of Buddha figures in some regions 
of Tang. The stamping technique must have been introduced from India to China, generally speaking, between Emperor Taizong's Zhenguan era (627-649) and Emperor Gaozong's Xianqing era (656-660). This method for producing Buddha figures with Buddha seals is merely stamping, which does not equate to genuine woodblock printing. Nevertheless, the Buddha seals offered by Silanaga to the Tang envoy reflect that stamping Buddha images using seals was indeed a rarity in the Tang dynasty and that printing, far more advanced than stamping, had not yet been invented in Tang China. Otherwise, there might have been no need for Wang to bring the Buddha seals back from India, thousands of miles away.

Despite the discovery of some similarly stamped Buddha figures in Dunhuang documents, these images are outnumbered by the enormous quantity of hand-written sutras dating from the same period. The fewer instances of hand-drawn Buddha figures are indicative that although those with a basic education were mostly able to write, painting was a specialized and rare skill. It could be, in fact, the high social demand for drawing that drove Wang to formally bring the Buddha seals from India.

Therefore, if the Buddha seal was the direct origin of printing, the application in China may have largely resulted from the predicament confronting sutra writers. This could help clarify why images, which now seem more difficult than texts in terms of engraving blocks, could be the earliest precursor to the invention of printing. Tokushi particularly stated that although the Buddha seal and the similar pagoda seal for stamping Buddha or pagoda images were prevalent in India and applied on paper, paper was not commonly employed for writing in India. There, pattra leaves were widely used for writing, but was an ill-suited to stamp images using the Buddha seal and pagoda seal. This significant point from Tokushi implies that this was the reason why printing as a result of the Buddha seal and pagoda seal was invented in China, where the seals were imported, rather than in India, the exporter. To be more specific, up until the visit of Wang Xuance and Yijing 义净, India was still importing paper from outside, and papermaking had not yet been introduced, making it impossible for paper to be a common medium for writing and for India to invent printing.

Notwithstanding the unlikelihood of printing having originated in India due to the mentioned restrictions, such as locally-produced paper, the application of the Buddha seal and pagoda seal among Indian Buddhists exerted a far-reaching impact on the early development of printing in China. As stated by Tokushi, Indian followers of Vajrayana would first stamp Buddha figures on silk or paper, and would then use the Buddha and pagoda seals to stamp a large number of images into sand, thereby establishing a conventional practice, or fixed ritual (yigui 仪轨), to exhibit the unique beliefs and concepts of Vajrayana. Such a ritual, characteristic of Vajrayana, naturally influenced the Chinese followers and became widespread in China.

The Vajrayana mentioned by Tokushi, namely Yoga Esotericism, was developed 
fully in India from the early sixth to the early eighth century and was referred to as Esoteric Buddhism after entering China. The earlier ancient Vajrayana in India had already been transmitted eastwards to China during the Three Kingdoms period (222280). After the Eastern and Western Jin dynasties (265-420), Vajrayana sutras of various kinds increasingly came to China, which were designated as "mixed esotericism" ( $z a$ mi 杂密), as opposed to the Esoteric Buddhism burgeoning after the mid-Tang dynasty.

It is generally considered that the visit of the Indian monk Subhakarasimha 善无畏 to China in the fourth year (716) of Emperor Xuanzong's Kaiyuan era marks the introduction of pure Indian Yoga Esotericism into China. In the eighth year (720) of the Kaiyuan era, another Indian monk Vajrabodhi 金刚智 and his disciple Amoghavajra 不空 (from the Lion Kingdom) promoted the Vajrayana doctrines in China. The utmost endeavors of these three masters of Vajrayana and Emperor Xuanzong's piety greatly popularized Esoteric Buddhism in the Tang dynasty. The devout belief among the upper class, especially imperial members and dignitaries, heavily impacted the public, who also sought blessings in this life and the afterlife. The prevalence of Buddhist belief was the most important social factor leading to printing. Without such piety, woodblock printing would not have been invented.

Prior to Subhakarasimha's visit to China, some eminent Chinese monks had already accessed and translated Vajrayana classics. Yijing, for instance, who introduced the usage of the Buddha seal to Tang China, translated Sutra of the Great Peahen Queen Spell (Da kongque zhou wang jing 大孔雀咒王经), a Vajrayana classic that was the first to deify Dharani as Vidyaraja 明王. Nonetheless, Chou Yi-liang 周一良 remarked that “[ $\mathrm{t}]$ heir work, though it achieved some degree of popularity, cannot be said to have established the cult as such" (Chou 1945, 245). It means that before the Kaiyuan era there was a slim chance that Vajrayana would have been universally and strongly worshiped, and thus Dharani would not have been printed by the public to demonstrate their earnestness.

How then were the Vajrayana sutras, which had been widely transmitted to China during the Wei, Jin, and Northern and Southern dynasties, changed during the Tang dynasty? During the $\mathrm{Wu}$ Zetian period, between seventeen and twenty-nine new Vajrayana sutra rituals were translated into Chinese, including the aforementioned Great Dharani Sutra. Osabe Kazuo 长部和雄 makes an intriguing comparison between the Vajrayana rituals based on translations of the Womb Realm (Garbhadhatu 胎藏界) and the Diamond Realm (Vajradhatu 金刚界) made in the Kaiyuan era and the Vajrayana treatises translated during the $\mathrm{Wu}$ Zhou dynasty. Osabe argues that the $\mathrm{Wu}$ Zhou era translations are characterized by the subjugation of demons and hellsmashing. Furthermore, they rarely touch upon the final dharma (mo fa 末法), buddhanusmrti-samadhi (nianfo sanmei 念佛三昧), and Pure Land of Bliss (Sukhavati 极乐世界) that would have effortlessly appealed to and earned fervent beliefs from the 
populace. In contrast, the juxtaposition of the hell with the paradise in The Great Dharani Sutra translated by Mitrasanta 弥陀山 and Fazang 法藏 in the Wu Zetian period is a rarity in the discussion of the Pure Land of Bliss in the Vajrayana sutras. The fact that The Great Dharani Sutra was among the first sutras to be printed is emblematic of the direct impact of the above notions on printing (Osabe 1982).

As discussed in the preceding section, the printing of the Sanskrit Dharani sutras in Tang China was based on the popularity of the debuted Chinese translations and the belief held by Tang worshippers that the Sanskrit versions carried greater efficacy. This pervading idea is more explicitly documented in A Catalog of Buddhist Teachings, Newly Collated in the Zhenyuan Era (Zhenyuan xinding shijiao mulu 贞元新定释教目录), which states that people from all walks of life, from the emperor to the general public, believed Dharani prints in Sanskrit to be mightier than those in Chinese when carried with oneself (Shi 1927, 883).

In this case, the stamping technique for Buddha figures was used to produce the highly demanded Dharani sutras, as most people were incapable of writing in Sanskrit. The earliest printed text, along with the popularization of Vajrayana in the Kaiyuan era, should thus be the stamped Dharani sutras in Sanskrit, while the invention and application of true woodblock printing came afterwards. The size of the stamping plate, however, was limited - if it had been any larger, the plate could not have been evenly covered with ink. Though relatively short in length, the Dharani sutras still required larger plates compared with a single Buddha image.

As previously discussed, Su Bai explored the sequence of different versions of Dharani prints, showing that the Sanskrit prints using separate plates came before the Chinese woodblock prints using a whole carved block. The utilization of several plates for successive stamping was an obvious transition from the small Buddha seal to the large woodblock. After a period of this transition, people naturally realized that the plate consisting of several small Buddha seals could be remade into a single large block, the carved surface of which could be turned upward - hence a complete leaf of Dharani could be printed at once-the birth of woodblock printing.

Regarding the sequence of Dharani prints, besides the earlier stamping technique using a few small plates, Su Bai stressed that after the Sanskrit version came the Chinese one, and that the print in Chinese was the initial extension of the newly invented technique of printing to other fields.

Followers of Chinese Buddhism believed woodblock-printed sutras to be more efficient and higher quality than handwritten sutras as they were accustomed to writing sutras - the longer the better-to accrue their merits and virtues. Ordinary worshippers, whose faith was not strictly confined to any particular school of Buddhism, eventually embraced the Dharani prints in Chinese, as they proved more convenient in showing their reverence for Buddha. The application of woodblock 
printing was consequently extended from Vajrayana to all Buddhist believers.

The impact of the public's practices of Buddhist beliefs was soon seen in other aspects of their social lives. As mentioned in the second section, the Dongchuan commander Feng Su's proposal of banning unauthorized almanac woodblocks in the ninth year of the Taihe era indicates that printing almanacs using woodblocks was already popular at that period. In the third year (883) of the Tang Emperor Xizong's Zhonghe era, Liu Pin 柳玭 witnessed "an abundance of books on miscellaneous subjects, such as yin and yang, dream-interpreting, house divination, astronomy, dictionaries, and philology, all woodblock-printed but blurry and only partially readable" at bookstores in Chengdu. ${ }^{7}$ The range of printing expanded to introductory books such as dictionaries and philosophical treatises for literary learning. "Blurry and only partially readable," as the printing quality was, the brand-new bookmaking technique of woodblock printing revealed its significance for the first time and was irresistibly adopted to make the upper-level historical classics.

\section{Conclusions}

From the above discussions three conclusions can be drawn. First and foremost, given that a large number of replicas of The Great Dharani Sutra of Immaculate and Pure Light were needed for enshrinement and worship, the single sutra replica stored in Silla could not have been produced there; thus, the origin of printing is irrelevant to the Korean Peninsula. Secondly, the claims that woodblock printing originated in the Sui dynasty, in Tang Emperor Taizong's era, or in the Wu Zhou period are insufficiently grounded in evidence. The earliest application of woodblock printing in the Tang dynasty can be no earlier than the Kaiyuan era (713-741). Thirdly, the transmission of Indian Yoga Esotericism into China in the early Kaiyuan era led to the popularity of sutra rituals, which stemmed from the stamping of Buddha figures using seals and was the most direct driving force for the origin of printing.

\section{References}

An, Jiayao 安家瑶, and Feng Xiaotang 冯孝堂. 1998. “Xi'an Fengxi chutu de Fanwen Tangyinben Tuoluoni jingzhou” 西安泮西出土的梵文唐印本陀罗尼经咒 [The Tang Print of the Sanskrit Dharani Sutra Unearthed in Fengxi, Xi'an]. Kaogu 考古 [Archaeology], no. 5, 88-90.

Anonymous. 1936. Airizhai congchao 爱日斋从抄 [Collected Writings from the Airi Room]. In Congshu jicheng chubian 丛书集成初编 [The First Series of Collected Collectanea]. Facsimile of the Qing Daoguang edition in Shoushange congshu 守山阁丛书 [The Collectanea of the Mountain-Watching Pavilion]. Shanghai: The Commercial Press.

7 “其书多阴阳杂说、占梦相宅、九宫五纬之流, 又有字书小学, 率雕板印纸, 浸染不可尽晓。” Preface of Liu's Family Precepts (Liu shi jiaxun xu 柳氏家训序) (quoted in Anonymous 1936, 5). 
Carter, Thomas Francis. 1925. "The Beginnings of Block Printing in the Buddhist Monasteries of China." Chap. 6 in The Invention of Printing in China and Its Spread Westward, 28-32. New York: Columbia University Press.

Chen, Miaoying 陈妙英. 2000. “Zhongguo diaoban yinshuashu zhaoshi yu Sui (xia)” 中国雕版印 刷术肇始于隋（下） [Woodblock Printing Originating from the Sui Dynasty of China (part 2)]. Yinshua zazhi 印刷杂志 [Printing Field], no. 11, 175-176.

The Chosun Ilbo. 2007. "Age of Famed Woodblock Printing Still a Mystery." October 29, 2007. http://english.chosun.com/site/data/html_dir/2007/10/29/2007102961011.html.

Chou, Yi-liang. 1945. “Tantrism in China." Harvard Journal of Asiatic Studies 8 (3-4): 241-333.

De, Xin 德新, Zhang Hanjun 张汉君, and Han Renxin 韩仁信. 1994. “Neimenggu Balinyouqi Qingzhou Baita faxian Liaodai fojiao wenwu” 内蒙古巴林右旗庆州白塔发现辽代佛教文物 [The Liao Buddhist Relic Discovered in the White Pagoda in Qingzhou, Bairin Right Banner, Inner Mongolia]. Wenwu 文物 [Cultural Relics], no. 12, 4-33.

Feng, Zhi 冯贽. 2006. Yunxian sanlu 云仙散录 [A Desultory Record of the Cloud Immortal] Facsimile of the Song Kaixi block-printed edition in Nanjing Library. China Rare Books Reprinted Collection. Beijing: Beijing Library Press.

Fujita, Toyohachi 藤田豐八. 1930. 支那印刷の起源につきて [On the Origin of Printing in China]. In 劍峰遺草 [Posthumous Manuscripts of Fujita Toyohachi]. Tokyo: Sanshusha.

Goodrich, L. Carrington. 1967. "Printing: Preliminary Report on a New Discovery." Technology and Culture 8 (3): 376-378.

$\mathrm{Hu}$, Shi 胡适. [1959] 1998. “Lun Chutang Shengtang hai meiyou diaoban shu” 论初唐盛唐还没有雕 板书 [On the Absence of Woodblock-Printed Books in the Early Tang to the High Tang Periods]. In Ziyou Zhongguo 自由中国 [Free China]. Reprinted in Hu Shi wenji 胡适文集 [Collected Works of Hu Shi], edited by Ouyang Zhesheng 欧阳哲生. Beijing: Peking University Press.

Huang, Yongnian 黄永年. 2005. “Diaoban yinshua de chuxian” 雕版印刷的出现 [The Invention of Woodblock Printing]. In “Banben shi he banben jianbie” 版本史和版本鉴别 [The History of the Study of Editions and Edition Identification]. Chap. 3 in Guji banbenxue 古籍版本学 [The Study of Editions of Ancient Books]. Nanjing: Jiangsu Education Press.

Hundunsheng 混沌生 (Wang Huimin 王惠民). 1925. 燉煌出大業三年の佛畫に就て [The Buddha Image in the Third Year of the Daye Era Uncovered in Dunhuang]. Kokka 國華, no. 416, 203-204.

Kanda, Kiichiro 神田喜一郎. 1976. 中国におけ的印術の起源について[On the Origin of Printing in China]. 日本学士院紀要 [Proceedings of the Japan Academy] 34 (2): 94.

Kawase, Kazuma 川濑一馬. 1984. “Shiragi Bukkokuji Shakatō-shutsu no Muku jōkō dai daranikyō ni tsuite” 新羅仏國寺釋迦塔出の無垢浄光大陀羅尼經について[The Great Dharani Sutra of Immaculate and Pure Light Uncovered in the Seokgatap Pagoda at the Bulguksa Temple, Silla]. Shoshigaku 書誌学, nos. 33-34, 1-9.

Kim, Sung-Soo 金聖洙. 1994. 韓國木板印刷의 起源年代에 관한 研究 [A Study on the Origin of Korean Woodblock Printing]. 書誌学研究 10:425-478.

Kim, Sung-Soo. 2003. 『無垢淨光經』의 刊行에 관한 中國측 反論에 대한 批判 [Rebuttal of the Chinese View on the Publication of The Great Dharani Sutra of Immaculate and Pure Light]. 書 誌学研究 25:477-506. 
Kuwabara, Jitsuzo 桑原隲藏. 1968. カー夕一氏著『支那に於ける印刷の起源』[Carter's The Invention of Printing in China]. Vol. 2 of Kuwabara Jitsuzo zenshu 桑原隲藏全集 [Complete Collection of Kuwabara Jitsuzō]. Tokyo: Iwanami Shoten.

Li, Ling 李翎. 2011. “Dasuiqiu Tuoluoni zhou jing de liuxing yu tuxiang” 《大随求陀罗尼咒经》的 流行与图像 [The Popularity and Images of Mahapratisara Dharani Sutra]. In Fojiao yu tuxiang lungao 佛教与图像论稿 [The Argumentation on Buddhism and Images]. Beijing: Cultural Relics Publishing House.

Li, Xingcai 李兴才. 1990. “Lun Zhongguo diaoban yinshua shi de jige wenti” 论中国雕版印刷史 的几个问题 [On Several Issues Regarding the History of Woodblock Printing in China]. In Diaoban yinshua yuanliu 雕版印刷源流 [The Origin and Development of Woodblock Printing], edited by the Banknote-Printing Branch of the Shanghai New Fourth Army Historical Institute 上海新四军历史研究会印刷印钞分会, 154-188. Beijing: Printing Industry Publishing House.

Mitrasanta 弥陀山, et al. trans. 1927. 无垢净光大陀罗尼经 [The Great Dharani Sutra of Immaculate and Pure Light]. In 密教部 [Esoteric Buddhist Section]. In 大正新修大藏经 [Revised Taisho Tripitaka]. Tokyo: Taisho Tripitaka Publication Association 大正一切经刊行会. Nakamura, Fusetsu 中村不折. 2003. “Xuyan” 绪言 [Introduction]. In Yuyu chutu mobao shufa yuanliu kao 禹域出土墨宝书法源流考 [On the Origin and Development of the Calligraphy Unearthed in China], translated by Li Defan 李德范. Beijing: Zhonghua Book Company.

Nakayama, Kyushiro 中山久四郎. 1930. 隋唐時代の雕版印刷 [Woodblock Printing in the Sui and Tang Dynasties]. Chap. 1, part 2 in 支那篇 - 朝鮮篇 [Shina: Korea]. Vol. 2 of 世界印刷通 史 [A Comprehensive World History of Printing]. Tokyo: Sanshusha.

Needham, Joseph, and Tsien Tsuen-Hsuin. 1985. "Beginning of Woodblock Printing." In Chemistry and Chemical Technology: Paper and Printing, 146-158. Vol. 5, part 1 of Science and Civilisation in China. Cambridge: Cambridge University Press.

Osabe, Kazuo 長部和雄. 1982. 則天武后時代の密教 [Esoteric Buddhism during the Reign of Wu Zetian]. In 唐宋密教史論考 [Studies on Esoteric Buddhism in the Tang and Song Dynasties], 1-33. Kyoto: Nagata Bunshōdō.

Pan, Jixing. 1997. "On the Origin of Printing in the Light of New Archaeological Discoveries." Chinese Science Bulletin 42 (12): 976-981.

Pan, Jixing 潘吉星. 2002. “Muban yinshua he tongban yinshua de faming” 木板印刷和铜版印刷的 发明 [Invention of Woodblock Printing and Copper Plate Printing]. Chap. 3, part 2 in Zhongguo gudai sida faming: Yuanliu waichuan ji shijie yingxiang 中国古代四大发明一一源流、外传及世界影响 [The Four Great Inventions of Ancient China: Their Origin, Development, Spread, and Influence in the World]. Hefei: Press of University of Science and Technology of China.

Qigong 启功. 1997. “Zhong Chao youhao wenhua jiaoliu lishi de xin jianzheng” 中朝友好文化交 流历史的新鉴证 [A New Verification of the History of Friendly Cultural Exchanges between China and Korea]. Zhongguo yinshua 中国印刷 [China Print], no. 2, 3, 19.

Shi, Huili 释慧立, and Shi Yancong 释彦悰. 1932. Datang Da Ci'en Si Sanzang fashi zhuan 大唐大 慈恩寺三藏法师传 [A Biography of the Tripitaka-Master of the Great Ci'en Monastery]. Collotype print of the Korean edition. Kyoto: Huiwentang 汇文堂.

Shi, Yuanzhao 释圆照. 1927. Zhenyuan xinding shijiao mulu 贞元新定释教目录 [A Catalog of Buddhist Teachings, Newly Collated in the Zhenyuan Era]. In Mulu bu 目录部 [Section of 
Catalogs]. Juan 15 of Dazheng xinxiu Dazangjing 大正新修大藏经. Tokyo: Taisho Tripitaka Publication Association 大正一切经刊行会.

Su, Bai 宿白. 1999. Tang Song shiqi de diaoban yinshua 唐宋时期的雕版印刷 [Studies on the Block Printings and Woodcuts of the Tang and Song Dynasties]. Beijing: Cultural Relics Publishing House.

Tokushi, Yusho 秃氏祐祥. 1951. 印刷術の發見 [A Glimpse into Printing]. Chap. 3 in 東洋印刷史 序說 [An Introduction to the History of Printing in Japan]. Kyoto: Heirakuji Shoten.

Tokushi, Yusho. 1981. 百萬塔陀羅尼考證 [Research on One Million Pagodas and Dharani Prayers]. In 東洋印刷史研究 [Research on the History of Printing in Japan]. Tokyo: Seishōdō Shoten.

Wang, Qinruo 王钦若, et al. 1960. Cefu yuangui 册府元龟 [Prime Tortoise of the Record Bureau]. In Ge bi 革弊 [Forsaking Malpractices]. Juan 160 of Diwangbu 帝王部 [Section of Emperors and Kings]. Facsimile of the Ming Chongzhen block-printed edition. Beijing: Zhonghua Book Company.

Xiang, Da 向达. 2001. “Tangdai kanshu kao” 唐代刊书考 [Books Published in the Tang Dynasty]. In Tangdai Chang'an yu Xiyu wenming 唐代长安与西域文明 [Chang'an of the Tang Dynasty and Civilization of the Western Regions]. Shijiazhuang: Hubei Education Press.

Xiao, Dongfa 肖东发. 2000. “Zhenye yi xungen guanlan er suoyuan: Zhongguo muban shuiyin gaishuo yu yinshuashu de qiyuan” 振叶以寻根 观澜而索源— 《中国木版水印概说》与印刷术 的起源 [Tracing the Root from Leaves and Seeking the Origin from the Torrent: Sketch of Chinese Water-Color Woodblock Printing and the Origin of Printing]. Zhongguo chuban 中国出版 [China Publishing Journal], no. 5, 43-44.

Xin, Deyong 辛德勇. 2016. Zhongguo yinshuashi yanjiu 中国印刷史研究 [On the History of Printing in China]. Beijing: SDX Joint Publishing.

Yi, Hong-jik 李弘稙. 1968. 慶州仏國寺釈迦塔発見の無垢淨光大陀羅尼経 [The Great Dharani Sutra found in the Seokgatap Pagoda at the Bulguksa Temple, Gyeongju]. Chōsen gakuhō 朝鮮 学報 [Journal of the Academic Association of Koreanology in Japan], no. 49, 457-482.

Zhang, Shudong 张树栋. 2000. “Youguan yinshuashu qiyuan wenti de jige jiben gainian” 有关印 刷术起源问题的几个基本概念 [Several Basic Concepts Concerning the Origin of Printing]. Guangdong yinshua 广东印刷 [Guangdong Printing], no. 3, 60-61.

Zhang, Xiumin 张秀民. 1958. “Diaoban de faming” 雕板的发明 [The Invention of the Woodblock]. Chap. 1, part 2 in Zhongguo yinshuashu de faming jiqi yingxiang 中国印刷术的发明及其影响 [The Invention of Printing in China and Its Influence]. Beijing: People's Publishing House.

Zhang, Xiumin. 1988. “Nanchaoxian faxian de fojing wei Tangchao yinben shuo” 南朝鲜发见的佛 经为唐朝印本说 [The Theory of the Buddhist Sutra Found in South Korea Being a Tang Print]. In Zhang Xiumin yinshua shi lunwenji 张秀民印刷史论文集 [The Collection of Zhang Xiumin's Articles on the History of Printing], 51-54. Beijing: Printing Industry Publishing House. 